\title{
Expression of Nestin, Transcription Factor SOX3 and Homeobox Protein DLX-4 in the Facial Tissue of Children with Cleft Lip and Palate
}

\author{
Expresión de Nestina, Factor de Transcripción SOX3 y Proteína Homeobox DLX-4 \\ en el Tejido Facial de Niños con Fisura Labiopalatina
}

Elga Sidhom \& Mara Pilmane

SIDHOM, E. \& PILMANE, M. Expression of nestin, transcription factor SOX3 and homeobox protein DLX-4 in the facial tissue of children with cleft lip and palate. Int. J. Morphol., 36(3):991-996, 2018.

SUMMARY: The failure of fusion of nasal and maxillary processes results in cleft lip and palate (CLP), which is one of the most common birth defects. The morphopathogenesis of this pathology is multifactorial and still largely unclear. The aim of this study was to evaluate the presence of nestin, transcriptor factor SOX3 (Sox3) and homeobox protein DLX-4 (Dlx-4) in complete unilateral (CU) and complete bilateral (CB) CLP affected facial tissue. Oral mucosa tissue samples were obtained from 17 CUCLP and 13 CBCLP patients during surgical cleft correction and 6 unaffected control subjects. Obtained tissue sections were stained with hematoxylin and eosin and by immunohistochemistry for nestin, Sox 3 and Dlx-4. The intensity of staining was graded semiquantitatively. Nestin-positive structures were detected in all CUCLP and CBCLP patients' tissue samples, varying from moderate number of nestin-positive structures to numerous. Sox 3 immunoreactivity was more prominent in epithelial cells in both patient groups with frequently patchy distribution. Mainly moderate number of Dlx-4-positive cells was observed in most of tissue samples. Statistically significant moderate positive correlation was found between nestin and Sox 3 factors in CUCLP patient group (Spearman's rank correlation coefficient $=.517, \mathrm{P}=.034$ ). Increase of nestinpositive structures suggests its role in the regulation of the remodeling of tissue in both CUCLP and CBCLP affected tissue. Dominance of Sox3 positivity in cleft affected epithelium indicates its possible role in (compensatory) formation of defective oral epithelium of CUCLP and CBCLP patients. The reduced expression of Dlx-4 implicates its limited regulatory role on the craniofacial development in CUCLP and CBCLP affected tissue.

KEY WORDS: Cleft lip and palate; Nestin; Transcriptor factor SOX3; Homeobox protein DLX-4.

\section{INTRODUCTION}

Orofacial clefts (most commonly cleft lip with or without cleft palate) are one of the most common birth defects with multifactorial etiology and impact on the oral health. Genetic components play an important role in the pathogenesis of cleft lip and palate (CLP), nevertheless the exact genetic predisposing factors involved in the development of CLP are still largely unknown (Ludwig et al., 2016). Apart of genetic involvement also such factors as ethnical background, geographic origin, socioeconomic status and environmental factors are related to the possible development of CLP (Waltrick-Zambuzzi et al., 2015).

The normal development of the maxilla during early intrauterine life involves the fusion of medial nasal processes in addition to bilateral maxillary processes. The failure of fusion of these processes results into CLP. In complete unilateral cleft lip and palate (CUCLP) the maxilla is divided into one bigger and one smaller segment, while in complete bilateral cleft lip and palate (CBCLP) the maxilla is segmented into two posterior segments and the pre-maxilla (Spina, 1973; Garib et al., 2015).

Nestin is an intermediate filament protein expressed during the development of the central nervous system, heart and skeletal striated muscle. It is especially upregulated during the differentiation of stem cells. Nestin is not found in adult tissues apart from stem and progenitor cells, as well as regenerating tissues (Berry et al., 2013). Palate possesses high regenerative capacity and is well innervated. Wounds of oral mucosa within the orofacial tissue heal very rapidly. Possibly, neural crest-related stem cells expressing nestin can be isolated from mammalian periodontal 
ligament or dental pulp (Widera et al., 2009). Cells with stem cell or progenitor cell properties expressing nestin have been isolated also from a mixed population of fibroblast-like and epithelial-like cells within the minor (primary labial) salivary glands (Andreadis et al., 2014). High-intensity staining and a high proportion of nestinpositive cells are significantly associated with a poor prognosis in primary malignant melanoma of the oral cavity (Kuk et al., 2016).

Transcriptor factor SOX3 (Sox3) belongs to SoxB1 subgroup of the Sox protein family. Sox3 plays an important role in neural and gonadal development, and is required for sex differentiation (Gao et al., 2015). Sox 3 is expressed in the ventricular zone of the embryonic and postnatal cerebellum and its expression is restricted to the glial cell system in the cerebellum during development and after birth (Cheah \& Thomas, 2015). Proper head and craniofacial development takes place under strict control of neural progenitor cell transformation into neural crest stem cells. The cell fate and therefore the correct orofacial development are determined by SoxB factors (Mandalos \& Remboutsika, 2017). Significant decrease in quantity and distribution of Sox 3 in vivo in zebrafish embryonic brain is associated with induced malformation (Wang et al., 2015).

Homeobox protein DLX-4 (Dlx-4) is expressed in the mesenchyme derived from neural crest cells in the first pharyngeal arch or primordium of the jaw. While in normal adult tissues Dlx-4 is absent, it has been found in a variety of malignancies. Expression of Dlx-4 is associated with acute leukemia, lung cancer, colorectal cancer and breast cancer (Wu et al., 2015). Dlx-4 has the ability to induce cancer cells to undergo epithelial to mesenchymal transition and accordingly to enhance tumor migration, invasion and metastasis (Zhang et al., 2012). Dlx-4 can regulate the placental development and altered immunoreactivity for Dlx-4 is linked to idiopathic fetal growth restriction (Murthi et al., 2006). Overall, Dlx-4 is likely to play a role in development at the mesenchymalepithelial boundary of placenta as well as other tissues (Morrish et al., 2001).

The aim of this study was to evaluate the presence of nestin, Sox3 and Dlx-4 in CUCLP and CBCLP facial tissue to identify their possible role in the multifactorial orofacial morphopathogenesis.

\section{MATERIAL AND METHOD}

Patients. Tissue samples were collected from the Cleft Lip and Palate Centre at the Institute of Stomatology of Riga Stradins University from 17 patients with CUCLP and 13 patients with CBCLP, and 6 unaffected control subjects. The CUCLP patient group consisted of 11 males and 6 females ranging in age from 9 months to 9 years and 4 months. The CBCLP patient group consisted of 8 males and 5 females in age range from 9 months to 9 years and 10 months. The control subjects were 6 to 9 years old. Tissue samples of oral mucosa were collected during cleft correction surgery in patient group or tooth extraction in control subjects.

The study was performed in accordance with the ethical standards laid down in the 1964 Declaration of Helsinki. All tissue samples were obtained after fully explaining the nature of the study to the parents of all patients and receiving written informed consent. The study was approved by the Ethical Committee at Riga Stradins University, permit issued in 2003.

Tissue sample preparation. Oral mucosa tissue was fixed in Stefanini's solution (Stefanini et al., 1967), dehydrated and embedded in paraffin. Further four micrometers thick sections were prepared and stained routinely with hematoxylin and eosin (Fischer et al., 2008).

Immunohistochemistry. Nestin (code ab5968, obtained from mouse, dilution 1:250, Abcam, UK), Sox3 (code orb158460, obtained from rabbit, dilution 1:200, Biorbyt Limited, Cambridge, UK) and Dlx-4 (code orb160775, dilution 1:100, Biorbyt Limited, Cambridge, UK) primary antibodies were used by biotin - streptavidin immunohistochemistry (IMH) (Hsu et al., 1981).

Samples were examined on Leica DC 300F camera, further image processing and analysis was performed on Image Pro Plus 6.0 software (Media Cybernetics, Silver Spring, Maryland, USA).

The intensity of immunostaining was graded semiquantitatively with no positive structures in the visual field being labeled as 0 , few positive structures in the visual field were labeled with + , moderate number of positive structures in the visual field was labeled with ++ , numerous positive structures in the visual field were labeled with +++ , abundance of positive structures in the visual field was marked with ++++ (Pilmane et al., 1995).

Statistical analysis. For statistical analyses nonparametric statistics and Spearman's rank correlation coefficient were used, $\mathrm{P}<0.05$ was considered statistically significant (Christensen, 1996). 


\section{RESULTS}

Nestin-positive structures were detected in all CUCLP and CBCLP patients' tissue samples, varying from moderate number $(++)$ of nestin-positive structures to numerous (+++) (Fig. 1). Nestin expressed in epitheliocytes, fibroblasts and macrophages, as well as nerve fiber bundles. When observing nestin-positive cells in epithelium, mainly basal epitheliocytes were positive. In some of our patients' oral mucosa nestin showed patchy immunoreactivity. Overall the total number of nestin-positive structures was higher in CBCLP tissue samples. Meanwhile, unaffected oral mucosa specimens showed numerous (+++) nestin-containing epitheliocytes and abundance $(++++)$ of nestin-containing connective tissue cells.

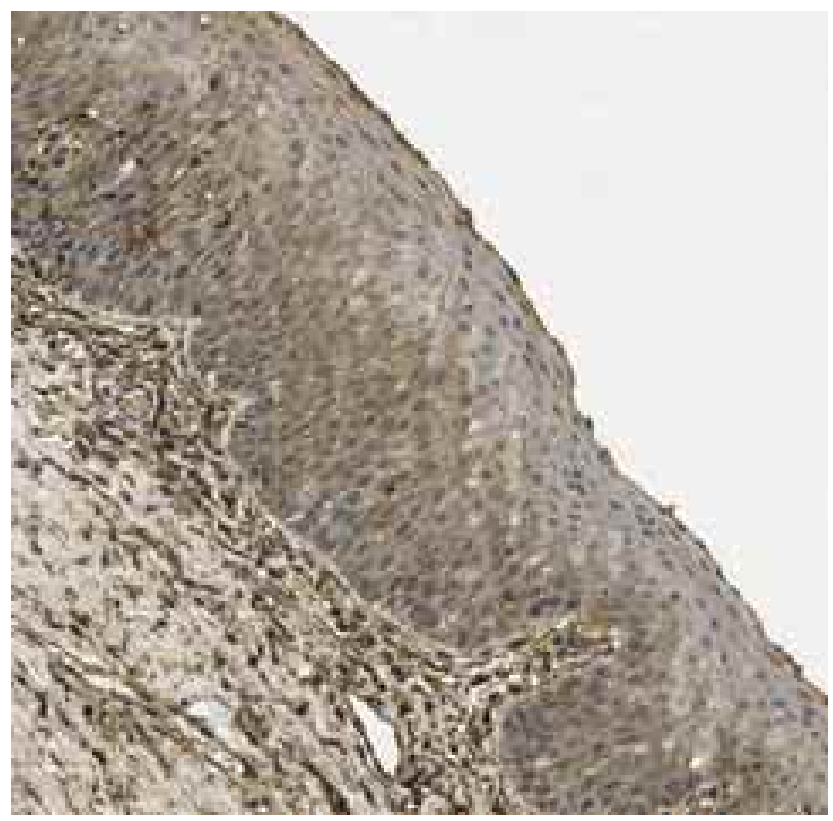

Fig. 1. Moderate number of nestin-positive oral epitheliocytes and numerous nestin-containing fibroblasts and macrophages in the lip tissue of 9 months old boy with CBCLP. Nestin IMH, $\times 200$.

Sox3-containing epitheliocytes, macrophages, as well as fibroblasts were found in all CUCLP and CBCLP patients' tissue samples, varying from few (+) Sox3-positive structures to numerous (+++) in the visual field. Sox 3 immunoreactivity was more prominent in epithelial cells in both patient groups. Sox3-positive epitheliocytes in many of our tissue samples showed patchy distribution and dominated in the prickle cell layer (Fig. 2). Moderate number (++) of epitheliocytes and connective tissue cells contained Sox 3 in control specimens.

Dlx-4-positive structures were found in 16 out of 17 CUCLP patients' tissue samples and 11 out of 13 CBCLP patients' tissue samples with mainly moderate number $(++)$

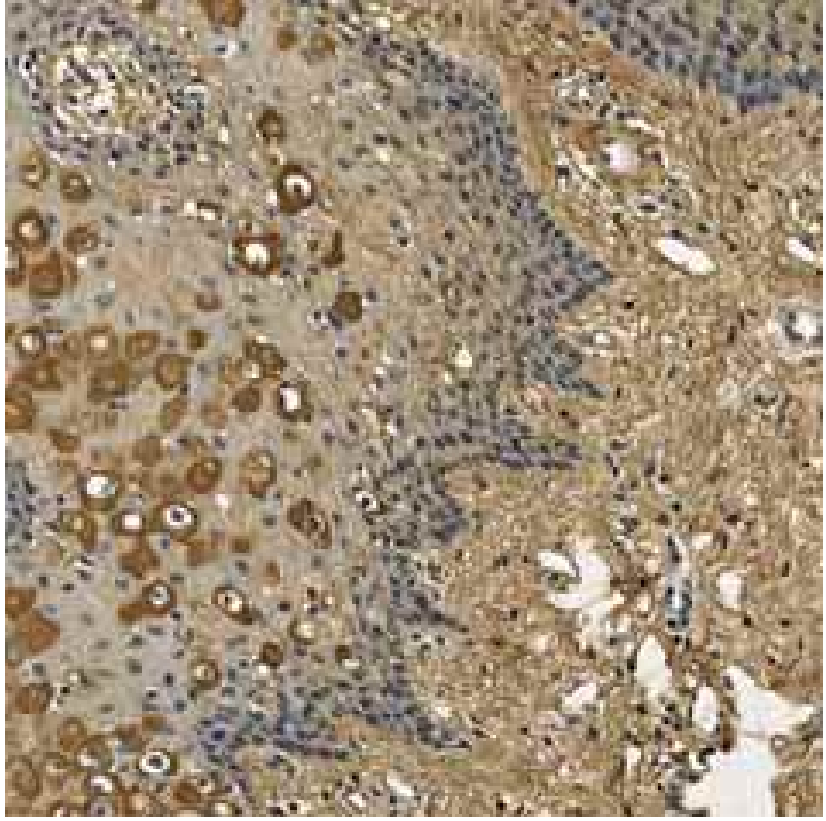

Fig. 2. Patchy distribution of Sox3-positive oral epitheliocytes in the lip tissue of 3 years and 4 months old boy with CBCLP. Sox 3 $\mathrm{IMH}, \times 250$.

of DLx-4-positive structures in the visual field. In one CUCLP patient tissue sample and two CBCLP patients' tissue samples we found no immunoreactivity for Dlx-4. Presence of Dlx-4 was found in epitheliocytes, often with patchy distribution, as well as fibroblasts and macrophages (Fig. 3). Only 4 control specimens contained few (+) Dlx-4positive epitheliocytes and connective tissue cells.

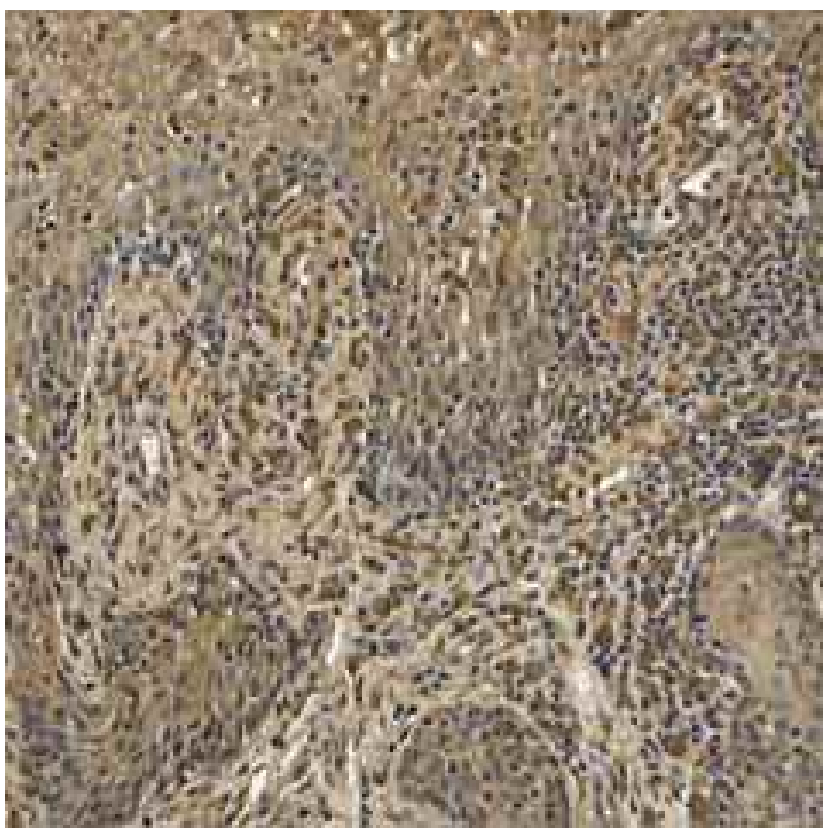

Fig. 3. Numerous Dlx-4-positive epitheliocytes and connective tissue cells in the lip tissue of 9 months old boy with CBCLP. Dlx$4 \mathrm{IMH}, \times 250$ 
Statistically significant moderate positive correlation was found between nestin and Sox 3 factors in CUCLP patient group (Spearman's rank correlation coefficient $=$ $.517, \mathrm{P}=.034)$.

\section{DISCUSSION}

CLP is a congenital malformation with disrupted facial development. While usually CLP is not associated with infant mortality, it requires corrective surgery and the patient can have feeding, speaking, hearing and dental problems, as well as social stigmatism. Both animal and human studies suggest that CLP similarly to neural tube defects has genetic component (Webber et al., 2015). Orofacial clefting involves the upper lip, alveolus and/or palate. Orofacial clefts are heterogeneous disorders affecting the structure of the face and oral cavity and are divided into three general categories: clefts affecting the lip only, clefts affecting the lip and palate, and clefts affecting palate alone (Leslie \& Marazita, 2013). In the current study all included patients had CUCLP (17 patients) or CBCLP (13 patients). Correct orofacial development is a strictly coordinated spatio-temporal sequence of events and includes cells migration, proliferation, differentiation, fusion and apoptosis. Disruption at any of these steps possibly will result as an orofacial cleft (Rahimov et al., 2012).

Nestin is essential for skin healing process. It has been observed In vitro that the healing after lip cleft reconstruction is remarkably better and with much less scaring if performed shortly after birth. Populations of keratinocytes and fibroblasts were studied and the expression of nestin was much stronger in newborns compared to older babies (Krejcí et al., 2015). Similarly the role of nestin in correct secondary palatogenesis, normal upper lip formation and cleft lip has been showed in transgenic mouse model (Li et al., 2008). It has been demonstrated that dental follicle contains an essential proportion of neural progenitor cells expressing nestin and could be a promising source of adult stem cells for regenerative purposes (Lima et al., 2017). Nestin has also been found in preneoplastic lesions of oral epithelium and possibly is associated with differentiation, invasion and poorer prognosis in oral squamous cell carcinoma (Ravindran \& Devaraj, 2015). In the facial tissue of 14 to 16 weeks old human fetuses using immunohistochemistry nestin-reactivity was seen in striated muscles, mesenchymal cells and fibers and the basal layer of the skin (Kim et al., 2016). In our study tissue samples showed prominent immunoreactivity for nestin with overall total number of nestin-positive structures higher in CBCLP tissue samples. We suggest that nestin plays a role in the regulation of the remodeling of cells in cleft affected tissue.
Sox 3 is important regulator for the neurogenic capacity of surface ectoderm and regulates the ability of the ectoderm to undergo neurogenesis (Tripathi et al., 2009). Craniofacial development is a complex multi-step process leading to the morphogenesis of the face and not only the neural crest development is affected; Sox 3 plays an equally crucial role in the pharyngeal region in craniofacial morphopathogenesis (Rizzoti \& Lovell-Badge, 2007). In the present study Sox3-containing epitheliocytes, macrophages and fibroblasts were found in all tissue samples with more prominent Sox 3 immunoreactivity in epithelial cells in both patient groups. Thus, Sox 3 is especially significant factor in the formation of defective oral epithelium of CUCLP and CBCLP patients.

Mainly moderate number of Dlx-4-positive epitheliocytes, fibroblasts and macrophages was found in most of our patients' tissue samples. Also Wu et al. suggests Dlx-4 as a potential cause of human clefts. A correlation between the loss of Dlx expression and either the loss of craniofacial cartilage elements originating from hindbrain crest cells or their abnormal morphology also has been observed (Ellies et al., 1997). Simultaneously, Dlx belongs to a group of factors that are important in odontogenesis, terminal differentiation of ameloblasts and with variable expression in odontogenic tumor formation in humans (Dodds et al., 2003). Therefore, we propose that the reduced expression of Dlx-4 implicates its wide regulatory role on the craniofacial development in CLP affected tissue.

Increase of nestin-positive structures suggests its role in the regulation of the remodeling of tissue in both CUCLP and CBCLP affected tissue. Dominance of Sox 3 positivity in cleft affected epithelium indicates its possible role in (compensatory) formation of defective oral epithelium of CUCLP and CBCLP patients. The reduced expression of Dlx4 implicates its limited regulatory role on the craniofacial development in CUCLP and CBCLP affected tissue.

ACKNOWLEDGEMENTS. Riga Stradins University project "Longitudinal research on cleft morphopathogenesis".

SIDHOM, E. \& PILMANE, M. Expresión de nestina, factor de transcripción SOX3 y proteína homeobox DLX-4 en el tejido facial de niños con fisura labiopalatina. Int. J. Morphol., 36(3):991998, 2018.

RESUMEN: La falla en la fusión de los procesos nasal y maxilar son causante de la fisura labiopalatina (FLP), que es uno de los defectos congénitos más comunes. La morfopatogenia de 
esta patología es multifactorial y aún poco clara. El objetivo de este estudio fue evaluar la presencia de nestina, el factor transcriptor SOX3 (Sox3) y la proteína homeobox DLX-4 (Dlx-4) en todo el tejido facial afectado por FLP bilateral unilateral (FU) y bilateral completa (FB). Se obtuvieron muestras de tejido de mucosa oral de 17 pacientes FUFLP y 13 FBFLP durante la corrección quirúrgica de la fisura y de 6 sujetos de control no afectados. Las secciones de tejido obtenidas se tiñeron con hematoxilina y eosina y mediante inmunohistoquímica para nestina, Sox3 y Dlx-4. La intensidad de la tinción fue graduada semicuantitativamente. Se detectaron estructuras positivas para nestina en todas las muestras de tejido de pacientes FUFLP y FBFLP, variando desde un número moderado a numerosas estructuras positivas para nestina. La inmunorreactividad de Sox3 fue más prominente en las células epiteliales en ambos grupos de pacientes con distribución frecuentemente irregular. Se observó un número principalmente moderado de células Dlx-4-positivas en la mayoría de las muestras de tejido. Se encontró una correlación positiva moderada estadísticamente significativa entre los factores de nestina y Sox3 en el grupo de pacientes FUFLP (coeficiente de correlación de rangos de Spearman $=0,517, \mathrm{P}=0,034$ ). El aumento de estructuras positivas para nestina sugiere su papel en la regulación de la remodelación de tejido, tanto en tejido afectado por FUFLP como FBFLP. La dominancia de la positividad de Sox3 en el epitelio afectado de la fisura, indica su posible papel en la formación (compensatoria) del epitelio oral defectuoso de pacientes FUFLP y FBFLP. La expresión reducida de Dlx-4 implica su función reguladora limitada en el desarrollo craneofacial en tejido afectado por FUFLP y FBFLP.

PALABRAS CLAVE: Fisura labiopalatina; Nestina; Factor transcriptor SOX3; Proteína homeobox DLX-4.

\section{REFERENCES}

Andreadis, D.; Bakopoulou, A.; Leyhausen, G.; Epivatianos, A.; Volk, J.; Markopoulos, A. \& Geurtsen, W. Minor salivary glands of the lips: a novel, easily accessible source of potential stem/progenitor cells. Clin. Oral. Investig., 18(3):847-56, 2014.

Berry, S. E.; Andruszkiewicz, P.; Chun, J. L. \& Hong, J. Nestin expression in end-stage disease in dystrophin-deficient heart: implications for regeneration from endogenous cardiac stem cells. Stem Cells Transl. Med., 2(11):848-61, 2013.

Cheah, P. S. \& Thomas, P. Q. SOX3 expression in the glial system of the developing and adult mouse cerebellum. Springerplus, 4:400, 2015.

Christensen, R. Analysis of Variance, Design and Regression: Applied Statistical Methods. London, Chapman \& Hall, 1996.

Dodds, A. P.; Cannon, R. E.; Suggs, C. A. \& Wright, J. T. mRNA expression and phenotype of odontogenic tumours in the v-Ha-ras transgenic mouse. Arch. Oral Biol., 48(12):843-50, 2003.

Ellies, D. L.; Langille, R. M.; Martin, C. C.; Akimenko, M. A. \& Ekker, M. Specific craniofacial cartilage dysmorphogenesis coincides with a loss of dlx gene expression in retinoic acid-treated zebrafish embryos. Mech. Dev., 61(1-2):23-36, 1997.

Fischer, A. H.; Jacobson, K. A.; Rose, J. \& Zeller, R. Hematoxylin and eosin staining of tissue and cell sections. CSH Protoc., 2008:pdb.prot4986, 2008.

Gao, J.; Li, P.; Zhang, W.; Wang, Z.; Wang, X. \& Zhang, Q. Molecular cloning, promoter analysis and expression profiles of the sox 3 gene in japanese flounder, Paralichthys olivaceus. Int. J. Mol. Sci., 16(11):27931-44, 2015.
Garib, D. G.; Rosar, J. P.; Sathler, R. \& Ozawa, T. O. Dual embryonic origin of maxillary lateral incisors: clinical implications in patients with cleft lip and palate. Dental Press. J. Orthod., 20(5):118-25, 2015.

Hsu, S. M.; Raine, L. \& Fanger, H. The use of antiavidin antibody and avidinbiotin-peroxidase complex in immunoperoxidase technics. Am. J. Clin. Pathol., 75(6):816-21, 1981.

Kim, J. H.; Jin, Z. W.; Murakami, G. \& Cho, B. H. Characterization of mesenchymal cells beneath cornification of the fetal epithelium and epidermis at the face: an immunohistochemical study using human fetal specimens. Anat. Cell Biol., 49(1):50-60, 2016.

Krejcí, E.; Kodet, O.; Szabo, P.; Borsk, J.; Smetana, K. Jr.; Grim, M. \& Dvoránková, B. In vitro differences of neonatal and later postnatal keratinocytes and dermal fibroblasts. Physiol. Res., 64(4):561-9, 2015.

Kuk, S. K.; Won, C. H.; Lee, W. J.; Shin, W. J.; Yoon, H. J.; Hong, S. D.; Hong, S. P. \& Lee, J. II. Prognostic significance of nestin in primary malignant melanoma of the oral cavity. Melanoma Res., 26(5):457-63, 2016.

Leslie, E. J. \& Marazita, M. L. Genetics of cleft lip and cleft palate. Am. J. Med. Genet. C Semin. Med. Genet., 163C(4):246-58, 2013.

Li, W. Y.; Dudas, M. \& Kaartinen, V. Signaling through Tgf-beta type I receptor Alk5 is required for upper lip fusion. Mech. Dev., 125(9-10):874$82,2008$.

Lima, R. L.; Holanda-Afonso, R. C.; Moura-Neto, V.; Bolognese, A. M.; DosSantos, M. F. \& Souza, M. M. Human dental follicle cells express embryonic, mesenchymal and neural stem cells markers. Arch. Oral Biol., 73:121-8, 2017.

Ludwig, K. U.; Ahmed, S. T.; Böhmer, A. C.; Sangani, N. B.; Varghese, S.; Klamt, J.; Schuenke, H.; Gültepe, P.; Hofmann, A.; Rubini, M.; Aldhorae, K. A.; Steegers-Theunissen, R. P.; Rojas-Martinez, A.; Reiter, R.; Borck, G.; Knapp, M.; Nakatomi, M.; Graf, D.; Mangold, E. \& Peters, H. Metaanalysis reveals genome-wide significance at $15 \mathrm{q} 13$ for nonsyndromic clefting of both the lip and the palate, and functional analyses implicate GREM1 as a plausible causative gene. PLoS. Genet., 12(3):e1005914, 2016.

Mandalos, N. P. \& Remboutsika, E. Sox2: To crest or not to crest? Semin. Cell Dev. Biol., 63:43-9, 2017.

Morrish, D. W.; Dakour, J. \& Li, H. Life and death in the placenta: new peptides and genes regulating human syncytiotrophoblast and extravillous cytotrophoblast lineage formation and renewal. Curr. Protein Pept. Sci., 2(3):245-59, 2001.

Murthi, P.; Said, J. M.; Doherty, V. L.; Donath, S; Nowell, C. J.; Brennecke, S. P. \& Kalionis, B. Homeobox gene DLX4 expression is increased in idiopathic human fetal growth restriction. Mol. Hum. Reprod., 12(12):7639, 2006.

Pilmane, M.; Luts, A. \& Sundler, F. Changes in neuroendocrine elements in bronchial mucosa in chronic lung disease in adults. Thorax, 50(5):551-4, 1995.

Rahimov, F.; Jugessur, A. \& Murray, J. C. Genetics of nonsyndromic orofacial clefts. Cleft Palate Craniofac. J., 49(1):73-91, 2012.

Ravindran, G. \& Devaraj, H. Prognostic significance of neural stem cell markers, Nestin and Musashi-1, in oral squamous cell carcinoma: expression pattern of Nestin in the precancerous stages of oral squamous epithelium. Clin. Oral Investig., 19(6):1251-60, 2015.

Rizzoti, K. \& Lovell-Badge, R. SOX3 activity during pharyngeal segmentation is required for craniofacial morphogenesis. Development, 134(19):343748, 2007.

Spina, V. A proposed modification for the classification of cleft lip and cleft palate. Cleft Palate J., 10:251-2, 1973.

Stefanini, M.; De Martino, C. \& Zamboni, L. Fixation of ejaculated spermatozoa for electron microscopy. Nature, 216(5111):173-4, 1967.

Tripathi, V. B.; Ishii, Y.; Abu-Elmagd, M. M. \& Scotting, P. J. The surface ectoderm of the chick embryo exhibits dynamic variation in its response to neurogenic signals. Int. J. Dev. Biol., 53(7):1023-33, 2009.

Waltrick-Zambuzzi, M.; Tannure, P. N.; dos Santos Vieira, T. C.; Antunes, L. S.; Romano, F. L.; Zambuzzi, W. F.; Granjeiro, J. M. \& Küchler, E. C. Genetic variants in folate and cobalamin metabolism-related genes 
in nonsyndromic cleft lip and/or palate. Braz. Dent. J., 26(6):561-5, 2015.

Wang, C.; Chen, X.; Shi, W.; Wang, F.; Du, Z.; Li, X.; Yao, Y.; Liu, T.; Shao, T.; Li, G. \& Hao, A. 2-Bromopalmitate impairs neural stem/progenitor cell proliferation, promotes cell apoptosis and induces malformation in zebrafish embryonic brain. Neurotoxicol. Teratol., 50:53-63, 2015

Webber, D. M.; MacLeod, S. L.; Bamshad, M. J.; Shaw, G. M.; Finnell, R. H.; Shete, S. S.; Witte, J. S.; Erickson, S. W.; Murphy, L. D. \& Hobbs, C. Developments in our understanding of the genetic basis of birth defects. Birth Defects Res. A Clin. Mol. Teratol., 103(8):680-91, 2015.

Widera, D.; Zander, C.; Heidbreder, M.; Kasperek, Y.; Noll, T.; Seitz, O.; Saldamli, B.; Sudhoff, H.; Sader, R.; Kaltschmidt, C. \& Kaltschmidt, B. Adult palatum as a novel source of neural crest-related stem cells. Stem Cells, 27(8):1899-910, 2009.

Wu, D.; Mandal, S.; Choi, A.; Anderson, A.; Prochazkova, M.; Perry, H.; Gil-Da-Silva-Lopes, V. L.; Lao, R.; Wan, E.; Tang, P. L.; Kwok, P. Y.; Klein, O.; Zhuan, B. \& Slavotinek, A. M. DLX4 is associated with orofacial clefting and abnormal jaw development. Hum. Mol. Genet., 24(15):4340-52, 2015.

Zhang, L.; Yang, M.; Gan, L.; He, T.; Xiao, X.; Stewart, M. D.; Liu, X.; Yang, L.; Zhang, T.; Zhao, Y. \& Fu, J. DLX4 upregulates TWIST and enhances tumor migration, invasion and metastasis. Int. J. Biol. Sci., 8(8):1178-87, 2012

\author{
Corresponding author: \\ Elga Sidhom \\ Kronvalda blvd. 9 \\ Riga, LV-1010 \\ LATVIA
}

\section{E-mail: Elga.Sidhoma@rsu.Iv}

Received: 18-01-2018

Accepted: 22-03-2018 